\section{THE METEOROLOGY OF THE FUTURE}

\section{A VISION}

GREELY translated from the Japanese by one who is thankful that he does not live in Japan. The translator would remark that in importing our Western institutions it is of great consequence to appropriate likewise the spirit which pervades them. "Dead flies cause the ointment of the apothecary to send forth a stinking savour" (old Eastern proverb).

\section{(N.B.--This translation is dedicated to the Conncil of the Royal Society.)}

A QUIET people are the dead,

What stillness do they keep !

The battle rageth overhead,

But marreth not their sleep.

And yet that this is sometimes broke

Hath been revealed to me;

'Twas in eighteen hundred and eighty-one

At the bottom of the sea.

There lay poor Jack, his perils past,

No more to turn the quid,

Nor pipe his eye (since barnacles

Were feasting on the lid).

Long thin sea-ropes in tangled coils

Were round and round him curl'd,

Yea, scaly things above him swam,

Down in that green sea-world.

He could not weigh his anchor up,

He could not heave astern--

And thus in my bewildered ear

He spun his doleful yarn.

"Tauts not the storm that brought me here

"In Davy Fones's grip,

"But'truas because my mates and me

"Sailed in a rotten ship."

I answered him: But knowst thou not

That Plimsoll's noble band

Board every ship, and punch its ribs

Before it leaves the land.

No rotten beam but would be seen

By such a skilled detector-

The dead man groaned-" Alas! dear mate,

"They jobbed the ship's inspector.

"Not two hours' sailing from the Nore ${ }^{1}$

"The wind began to veer,

"The storm was strong, the ship was weak,

"And we were driven here."

Belay ! belay! thou man of Death,

Thy yarn won't hold together,

Dost thou not know we have a board

That telegraphs the weather?

A board that sits both night and day,

With facts and figures stored,

Why man alive!-The dead man groaned-

"Alas they jobbed the board."

Why dost thou groan thou man of death?

Why so blaspheme and cuss?

Their chairman sure was not the smith

To forge thy fetters thus?

His was a mind of many sides,

Well filled with $a$ and $b$,

And $x$ and $y$, and likewise $z-$

"But he didn't know the sea."

I Of course this word does not occur in the originai-only its Japanese e uivalent.
As thus he spake I forthwith said-

Well, even if this be true,

The captain makes not all the ship,

Now, what about the crew?

There's one I know_-_" Divine" doth best

Express his god-like presence;

"He knew the sea but never dived

Bencath its phosphorescence."

Then, I replied, there was a third,

In fame to none will yield,

He led the band who reaped renown

On India's famine field.

Was he the man to see thee die?

Thou wilt not tax him--come?

The dead man groaned-_" I met my death

Through a sun-spot maximum."

One more-the rover of the crew-

Hath sailed o'er many seas;

Come now, be reasonable, he-

"Was busy shelling peas."

I wakened up in sheer disgust,

And to myself I said,

The living man for prejudice

Is beaten by the dead.

THE SPECTRA OF CHEMICAL COMPOUNDS ${ }^{1}$

$\mathrm{I}$ this paper Mr. Moser discusses the question, whether chemical compounds have a spectrum of their own or whether they only show the superposed spectra of their elements. To those who have worked at the subject the question can hardly be called an open one. Ever since the too much neglected work of Mitcherlich it was proved that each compound has its own characteristic spectrum, and whatever evidence subsequent workers have added to the question, the merit of having decided it belongs solely to Mitcherlich.

Nevertheless Mr. Moser's work is a valuable one and for several reasons. Other questions still at issue are intimately connected and cannot be discussed without once more referring to Mitcherlich's work. Most of these questions are not as yet amenable to strict proof but must be decided by the common sense of those who work at the subject. It is therefore of importance that as many as possible should take up the question, and though each worker may add little to the stock of knowledge, the consensus of opinion, thus established, will advance the subject materially. It is a pleasure to find that Mr. Moser has apparently arrived at the same theoretical views which have formed the leading string during the last years to the experimental work of Lockyer and others in this country. Mr. Moser mentions the suggestion of Prof. Helmholtz that the line-spectra are due to the vibrations of an atom while the band spectra are due to the more complex molecule. This is precisely the view first put forward by Lockyer, and it has thus received a striking confirmation from an independent quarter.

Mr. Moser experiments on the changes which certain absorption spectra undergo by a variation first of the thickness of the absorbing layer, and secondly of the temperature. With regard to the variation of thickness of the absorbing layer the conclusions seem simple enough. The bands get darker and wider. The influence of temperature is divided into two parts. On the great majority of bands the increase of temperature has apparently the same effect as an increase of mass; that is, it increases the absorption.

It is more than probable that this increased absorption is really due to an increase in the number of molecules giving the absorption spectrum in question. If a gas is ` By James Moser (Pogg. Ann., vol. clx., p. 177.) 